\title{
Arbuscular mycorrhizal colonization of vascular plants from the Yungas forests, Argentina
}

\author{
Alejandra BECERRA $^{\text {a* }}$, Marta CABELLO $^{\mathrm{b}}$, Franco CHIARINI $^{\mathrm{a}}$ \\ a Instituto Multidisciplinario de Biología Vegetal, CONICET-UNC. C.C. 495. 5000 Córdoba, República Argentina \\ ${ }^{\mathrm{b}}$ Instituto Spegazzini, Facultad de Ciencias Naturales y Museo, Avenida 53, N 477, 1900 La Plata, República Argentina
}

(Received 21 November 2006; accepted 7 June 2007)

\begin{abstract}
In Argentina, the Yungas forests are among the ecosystems most affected by human activity, with loss of biodiversity. To assess the mycorrhizal status in these ecosystems, the roots of 41 native plant species belonging to 25 families were collected throughout the year from two sites of the Yungas forests. Roots were washed and stained to study the presence of arbuscular mycorrhizas (AM). Morphological types of arbuscular mycorrhizas (Arum and Paris-type) and colonization patterns were identified and photographed. All plants presented AM colonization. The AM colonization patterns varied from single intracellular aseptate hyphae, coils, appresoria, to vesicles and/or arbuscules. Among the species studied, the Paris-type colonization showed to be dominant. Results confirmed that AM hosts are predominant in the Yungas of South American forests.
\end{abstract}

Yungas / arbuscular mycorrhizal / Arum-type / Paris-type / Alnus forests

Résumé - Colonisation par les mycorhizes arbusculaires dans des plantes vasculaires des forêts des Yungas, Argentine. En Argentine, les Yungas constituent un des écosystèmes les plus atteints par l'activité de l'homme, avec la perte de biodiversité qui en découle. Pour évaluer le statut mycorhizien de ces écosystèmes, les racines de 41 plantes autochtones appartenant à 25 familles ont été collectées au cours de l'année dans deux sites des forêts des Yungas. Les racines ont été lavées et teintes afin de déterminer la présence des mycorhizes arbusculaires (MA). Les types morphologiques de MA (type Arum et Paris) et les patrons de colonisation ont été identifiés et photographiés. Toutes les plantes ont présenté une colonisation MA. Les structures fongiques intraracinaires comprenaient des hyphes intracellulaires sans cloison, des boucles, des appressoria, des vésicules et/ou des arbuscules. Le type de colonisation Paris est apparu comme dominant parmi les espèces étudiées. Les résultats confirment que les hôtes avec MA prédominent dans les forêts sudaméricaines des Yungas.

Yungas / mycorhizes arbusculaires / type Arum / type Paris / bois d'Alnus

\section{INTRODUCTION}

The Yungas, or Tucuman-Bolivian forests [20,49], which belongs to the humid subtropical South American ecosystems, have a great regional relevance due to their high diversity [15]. However, the Yungas are among the ecosystems most affected by human activity, with the consequent loss of biodiversity. In order to conserve biodiversity, not only is it necessary to identify areas with high diversity of species, but it is also necessary to preserve different areas to protect genetic and environmental variation [15].

The Yungas are located between 300 and 3000 masl [20]. Three main environmental units can be recognized: The Premontane Forest (300-600 m asl), at present almost completely transformed into an intensive agricultural area; the Montane Forest (600-1500 $\mathrm{m}$ asl), where forestry and cattle raising are practiced, and the Montane Cloud Forest (1500-3000 m asl), which is being replaced by anthropic grasslands for cattle raising in some sectors.

The latter environmental unit, the montane cloud forest, has been divided into three plant communities, namely, "Podocarpus parlatorei Pilg. (Podocarpaceae) forests", "Al-

*Corresponding author: abecerra@efn.uncor.edu nus acuminata Kunth (Betulaceae) forests", and "Sambucus peruviana Kunth (Caprifoliaceae) and Polylepis australis Bitt. (Rosaceae) forests" [20]. These forests represent feature units and constitute altitudinal levels where A. acuminata is a pioneer species that colonizes disturbed areas $[1,38]$.

Alnus acuminata is tolerant to infertile soils given its ability to form ectomycorrhizal (ECM) [3-7], arbuscular mycorrhizal (AM) [8] and actinorrhizal relationships with Frankia [22], which enables it to fix atmospheric nitrogen in natural and disturbed soils [24]. At the same time A. acuminata can improve soil fertility due to its seasonal fall of leaves [30]. The high fertility of the soils may be the determining factor for the high diversity of plants. These forests are mono-specific as regards the tree stratum, with a high dominance of $95 \%$ of A. acuminata [10], whereas there are 186 species of different shrubs and herbs that compose the understory [36,74].

Arbuscular mycorrhizas play a crucial role in the mineral nutrition of most plants, such the case of forest trees [66]. This symbiosis occurs across a wide range of environments, probably because mutualism enables plants to obtain nutrients more effectively [62]. The arbuscular mycorrhizal fungi diversity influences the composition of the plant community $[32,39,44,45,47,48,53,54,65,78]$. The presence of different AM fungi can hence influence competitive interactions among 
plant species and so influence the plant community composition [13].

The success of any ecosystem's reforestation effort is, therefore, likely to depend on the establishment of mycorrhizas $[29,46,55,69,71]$. Unfortunately, at present indigenous trees in the Yungas ecosystem are not being used for reforestation purposes. On the contrary, they are declining due to the ever-increasing demand for timber and to the need of agriculturally suitable land [61]. In the Yungas, an example of an indigenous tree used for firewood, pulp, and timber, is A. acuminata, which forms ECM and AM, P. parlatorei and P. australis forming AM colonization ([58], Becerra personal observation). Considering the predominance of ECM and AM associations in this ecosystem, both mycorrhizal fungi should receive special attention in indigenous tree seedling production and in any management/conservation program for these montane cloud forests.

The mycorrhizal status of certain families and genera is varied; it is important to evaluate mycorrhizas in terms of soil characteristics and the mycorrhizal status of the dominant species, and thus, the inoculum that prevails in any particular habitat $[2,25,26]$.

Attention has been focused on the mycorrhizas of forests in the humid tropics $[11,12,50,51,60,72,73,77]$, but there is little information concerning the distribution and abundance of these types of symbioses in the Yungas [3-8]. Little is known of this endangered ecosystem and an urgent call is made for its conservation. The aim of this study was to characterize and describe the mycorrhizal status of native plants in the Yungas forests of Argentina. This study will allow us to know the influence of mycorrhizal symbiosis on the forest structure and stability, in order to improve our knowledge of mycorrhizal biology and diversity for re-vegetation programs.

\section{MATERIALS AND METHODS}

\subsection{Sampling sites}

This study was carried out on two field sites in the Yungas, in the NW region of Argentina (NOA), namely: 1) Quebrada del Portugués, Tafí del Valle, (Tucumán Province), which is located at $26^{\circ} 58^{\prime} \mathrm{S} 65^{\circ}$ $45^{\prime} \mathrm{W}$, has an elevation of $2187 \mathrm{~m}$, an average precipitation between $1200-1500 \mathrm{~mm}$. The soil was characterized as Lythic Ustorthent [83], and 2) Sierra de Narváez, (Catamarca Province), located at $27^{\circ} 43^{\prime} \mathrm{S}$ $65^{\circ} 54^{\prime} \mathrm{W}$, at an elevation of $1820 \mathrm{~m}$, which has an average precipitation of $698 \mathrm{~mm}$. The soil was characterized as Typic Ustorthent [83]. Mean annual temperatures range from 5.8 to $24^{\circ} \mathrm{C}$ for both locations. The vegetation is a nearly homogeneous A. acuminata forest (height 6-15 m, age 20-30 years).

\subsection{Field collection and laboratory analysis}

Among the land vegetation cover in the Yungas (Tab. I), 41 frequent species from a total of 25 families were selected in the two sites during summer (March 2001), autumn (May 2002) and spring (November 2002). Their choice was estimated on the basis of the Braun-Blanquet [14] method, with an abundance scale of + to 5. In herbs, grasses, and ferns, the whole root systems of five individuals were sampled. In shrubs with deep root systems, soil samples of five
Table I. Land vegetation cover of the Alnus acuminata forest in Sierra de Narváez (Catamarca province) and Quebrada del Portugués (Tucumán province).

\begin{tabular}{lcc}
\hline & Sierra de Narváez & Quebrada del Portugués \\
\hline Tree cover $(\%)$ & $80-90$ & $80-90$ \\
Shrubs cover $(\%)$ & $<20$ & $15-20$ \\
Herbaceous cover $(\%)$ & 90 & 90 \\
\hline
\end{tabular}

individuals were carefully excavated around each selected plant to confirm the connection between roots and shoots. The samples were placed in plastic bags and stored at $4{ }^{\circ} \mathrm{C}$. Plant species were identified at the Museo Botánico de Córdoba.

\subsection{Analysis of root samples}

Plants were carefully cleaned of soil and their root systems were washed and fixed in FAA. The preserved roots were stained to study the presence of AM according to the technique described by Phillips and Hayman [67]. For each individual system, at least 50 root segments of $2 \mathrm{~cm}$ in length were firstly observed under a Leica M 420 stereoscopic magnifier and secondly mounted on glass slides for examination in a Kyowa 4-100X microscope. A root was considered AM colonized when the following structures were observed: arbuscules, vesicles, hyphal coils, intraradical aseptate hyphae, and appressoria. We also determined the AM morphological type of the species studied, to find out whether they were the Arum- or the Paris-type [76]. The quantification of the AM root colonization was estimated visually and characterized using five classes of mycorrhizal root colonization: Class I, 1-5\%, Class II, 6-25\%, Class III, 26-50\%, Class IV, 51-75\%, and Class V, 76-100\% [70].

\section{RESULTS}

Arbuscular mycorrhizal colonization was evident in all plant roots collected (Tab. II). Forty one plant species were analyzed, including 32 herbaceous dicotyledons, 3 shrubs, 4 pteridophytes, and 2 herbaceous monocotyledons. Arbuscular mycorrhizal fungi colonized all the plant species examined (Tab. II). Appresoria, aseptate intra and intercellular hyphae, vesicles, arbuscules, or hyphal coils were observed in the majority of the plant samples collected. Although the colonization pattern varied among the species, intracellular aseptate hyphae and vesicles were the most frequent AM structures present in the species studied (Tab. II).

Although external septate hyphae bearing clamp connections on the root surfaces were detected in two species, namely, Urtica lilloi (Hauman) Geltman (Urticaceae) and Selaginella sp. (Selaginellaceae), no evidence of ECM was found, nor were the mantle or the Hartig net that are usually present with them observed either. Root hairs were observed in these species.

Appresoria, coils, aseptate intracellular hyphae, vesicles of various shapes (oval, irregularly lobed, and rectangular) and arbuscules were present in the majority of the plant roots (Fig. 1) (Tab. II). 
Table II. Mycorrhizal status of the native plant species from the Yungas forest in Sierra de Narváez (Catamarca, C) and Quebrada del Portugués (Tucumán, T).

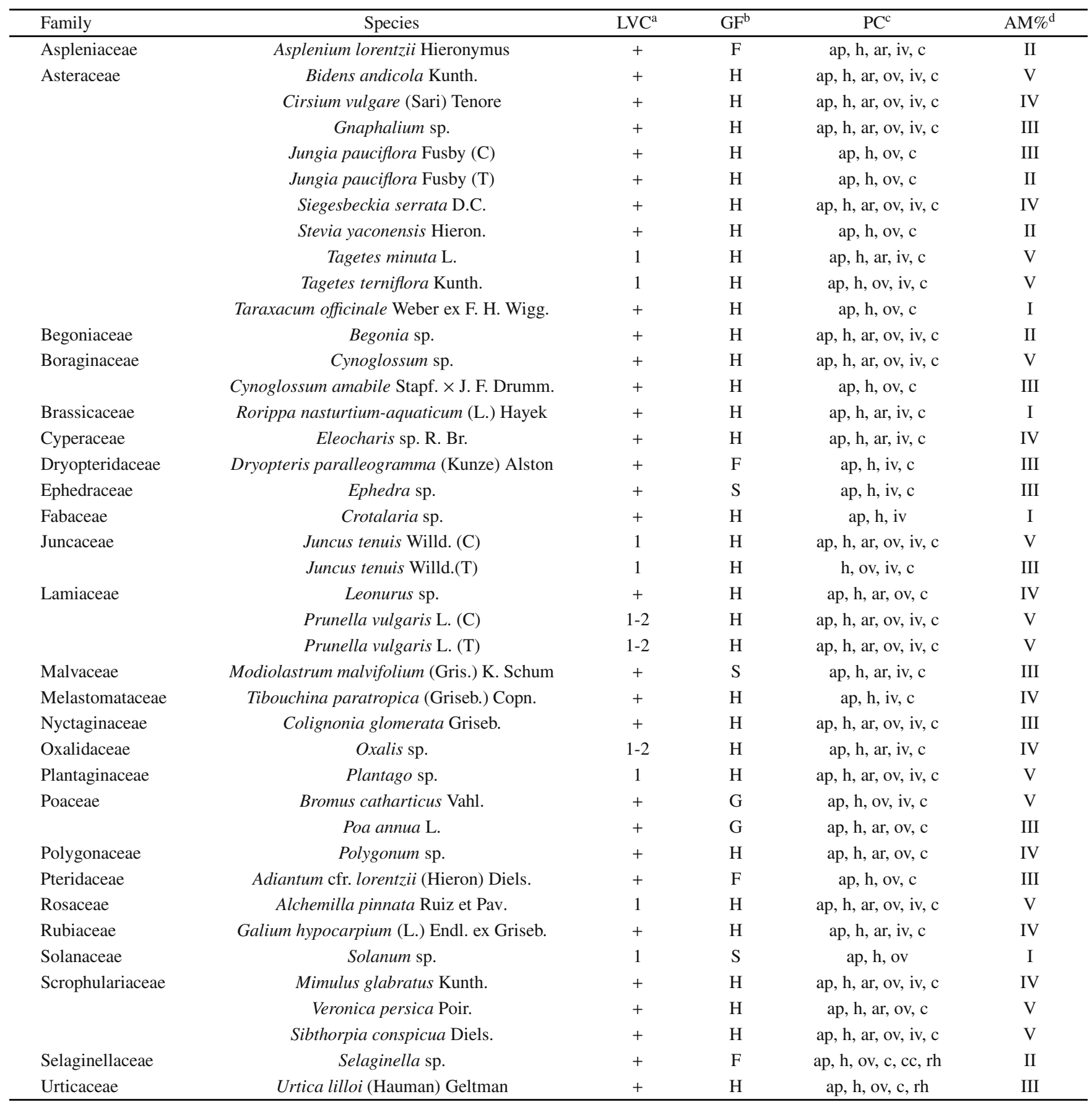

${ }^{a}$ LVC: land vegetation cover (LVC); +: <1\%, 1: 1-5\%, 2: 5-25\%.

${ }^{\mathrm{b}}$ GF: Growth form; H: herbs, G: grass, F: ferns, S: shrub.

${ }^{\mathrm{c}}$ PC: Patterns of AM colonization (PC); ap: appressoria, $h$ : intra- or intercellular aseptate hyphae, ar: arbuscules, ov: oval vesicles, $i v$ : irregular vesicles, $c$ : coils, $c c$ : septate hyphae bearing clamp connections, $r h$ : root hairs.

${ }^{\mathrm{d}}$ AM\%: AM colonization; Class I:1-5 \%, II: 6-25\%, III: 26-50\%, IV: 51-75\%, V: 76-100\%. 

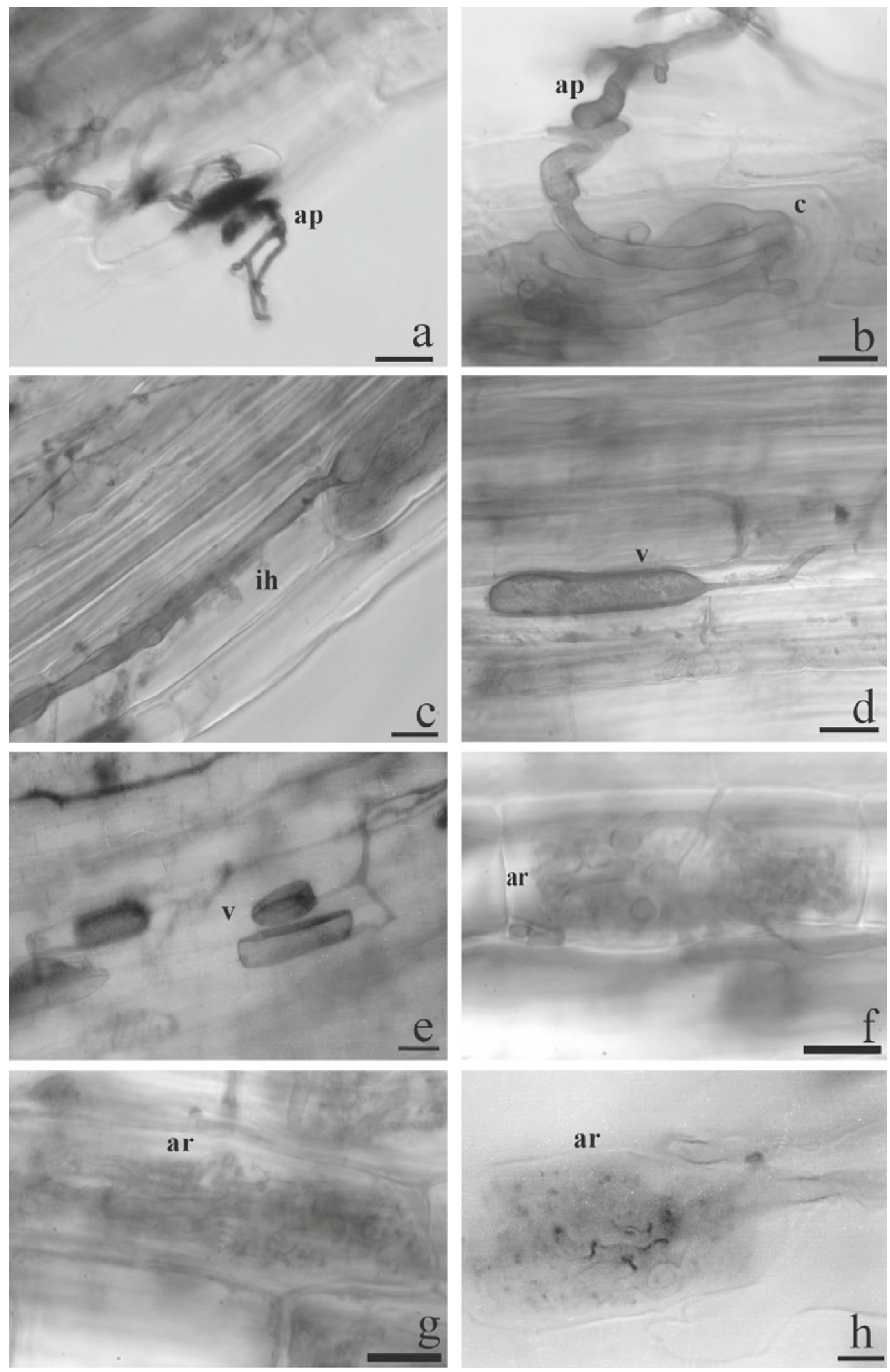

Figure 1. Structures of arbuscular mycorrhizas formed on roots of native plants of the Yungas forest, Argentina. (a) Appressoria (ap): Prunella vulgaris. (b) Appressoria and coils (ap, c): Bromus catharticus. (c) Intracellular hyphae (ih): Eleocharis sp.. (d, e) Vesicles (v): Juncus tenuis,

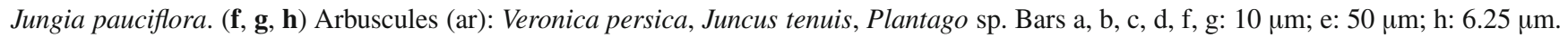


All the types of vegetation detailed in Table II are present in both forest sites. Some plants were sampled in both sites, in search of differences between AM colonization in the same plant species. The morphological colonization of the species Juncus tenuis varied in both sites (Tab. II). In Quebrada del Portugués we observed appresoria, hyphae, arbuscules, vesicles, and coils, while in Sierra de Narváez we only observed hyphae, vesicles, and coils. In the cases of Jungia pauciflora and Prunella vulgaris, no morphological colonization differences were observed in either of the sites.

In all the species studied, the colonization was Paris-type, since intracellular hyphae, intracellular hyphae coils, and terminal arbuscules were found. We also report the simultaneous development of separate and internally consistent infection units of Paris-type and Arum-type within the same root system in Crotalaria sp. and Solanum sp.

Arbuscular mycorrhizal colonization varied among the species studied (Tab. II). Four species had $1-5 \%$ of the root colonized with AM and five had less than 25\%. Only Bidens andicola, Tagetes minuta, Tagetes terniflora, Cynoglossum sp., Juncus tenuis, Prunella vulgaris, Plantago sp., Bromus catharticus, Alchemila pinnata, Veronica persica, and Sibthorpia conspicua had always more than $75 \%$ of the roots colonized with AM. The colonization of Juncus tenuis and Jungia pauciflora varied in both sites (Tab. II), with a low colonization degree in Quebrada del Portugués.

\section{DISCUSSION}

The mycorrhizal status of some herbs and shrubs of the NOA is reported for the first time. Bearing in mind that this study does not exclude the possibility of the occurrence of other kinds of mycorrhizal associations in the species examined, an absolute dominance of AM was observed in these plants. These results are in agreement with Janos' [52] and other authors' observations on the mycorrhizal status of neotropical forests $[12,77]$.

No evidence of ECM was found in any of the plant species studied, although in this forest Alnus acuminata has both types of mycorrhizas (ECM and AM) [3-8]. Both mycorrhizal types can occur, with a wide variation in degree of colonization, throughout the litter and the soil organic and mineral horizons, at least to a depth of $35 \mathrm{~cm}$ [60]. In stable forest communities, the soil and irradiance conditions may allow the persistence of an herbaceous understory of plants with AM beneath a canopy of predominantly ectomycorrhizal trees. However, different patterns of root distribution in the soil can provide niche separation for both types of mycorrhizas [75].

In this study, a mycorrhizal plant was categorized by the presence of arbuscules - generally used to designate plants with functional AM $[34,35]$ - or by the presence of hyphae and vesicles in the root samples [59,79]. The frequent occurrence of vesicles in the species studied indicates that a large part of the AM fungi belong to the Glominae, and diversity in vesicle shape indicates the presence of both Glomus (oval to ellipsoid vesicles) and Acaulospora (irregularly shaped to rectangular vesicles) (Tab. II) [19].
The AM status of all herbs and, in particular, the families Cyperaceae, Polygonaceae, Scrophulariaceae, and Juncaceae found here, contrasts with the predominantly non-mycorrhizal status previously recorded for these families [16, 18,40,41,75]. Redhead [68] considered the Polygonaceae family as ECM, although Tsuyuzaki et al. [82] observed a dual colonization (ECM and MA).

In the present study, as already found in others $[21,27,43$, 81], species belonging to the same family tended to have the same mycorrhizal behavior. However, several exceptions to this general rule were observed. For instance, Juncus tenuis belongs to a typically non-mycorrhizal family [75], but in this study it was found to be mycorrhized and showed mycorrhizal structures and colonization differences in both sites (Tab. II). Another case was that of the predominance of AM in Taraxacum officinale (Asteraceae), Rorippa nasturtium-aquaticum (Brassicaceae), and Eleocharis sp. (Cyperaceae), cited as nonmycorrhizal by Fontenla et al. [28]. Cases of species that contrast in their mycorrhizal status with taxonomically and phylogenetically closely related species have been pointed out in other studies $[29,56,57,80]$.

The Paris-type colonization found through this study was characterized by intracellular hyphae and intracellular hyphal coils, although arbuscules were always simple and terminal, never intercalary along the coils, as was described by Gallaud [31]. This variation of the Paris-type mycorrhizas has also been described by Gerdemann [33] and Bedini et al. [9]. The Paris-type was seen to be dominant in the herbaceous understory plants of the NOA, similar results were found by Yamato and Iwasaki [85] for herbaceous plants of the forests of the Kansai region. These facts indicate that the Paris-type is advantageous for herbaceous understory plants that grow slowly with low light intensity and low nutrient availability levels. On the other hand, O'Connor et al. [64] found the Arum-type in all of the 21 species of herbaceous AM plants that grow with no shading in the Australian desert. It is well known that the Arum-type is formed in most plants that usually grow in sunlight. The spreading rate of colonization is slower in the Paris-type than in the Arum-type. The slower colonization of the Paris-type might be beneficial for the host plants, since it probably keeps the energy supply to the fungi reduced and it might be desirable for plants of slow growth in a woodland environment [17]. Additionally, environmental factors such as temperature, light intensity and soil moisture content may influence AM morphology, as these factors affect the growth and morphology of roots $[23,84]$.

The ferns studied (Aspleniaceae, Dryopteridaceae, Pteridaceae, and Selaginellaceae) showed AM colonization. The occurrence of AM fungi in these families agrees with the reports of Harley and Harley [40], Newman and Reddell [63], Godoy et al. [37], and Zhao [86]. The presence of the Paristype predominates in ferns [76]. Only in one fern species we have observed arbuscules (Tab. II). The grasses Bromus catharticus and Poa апnиa showed AM colonization (Tab. II). These results are in agreement with the observations of Harley and Harley [40-42] and Fontenla et al. [28]. The presence of external fungal hyphae with clamp connections on Selaginella sp. root's surface is probably due to free-living saprobes. 
Further work is required to determine and understand the role of these fungi on Selaginella sp. roots.

This study showed a low AM colonization in the root samples of some species. Families such as Asteraceae, Brassicaceae, cited as non-mycorrhizal [28, 40,41], showed a low AM colonization. Regarding the extent of the AM colonization, the reported variations could be due to the different plant species which exhibit varied ability to establish mycorrhizal associations [75].

The results of this study showed differences with other findings cited in the literature. According to Brundrett [16], the generalities about the mycorrhizal status of plants in one floristic region should not be indiscriminately applied to another; taxonomic and environmental attributes of each community may influence the mycorrhizal behavior of each plant species.

These results must be considered preliminary, since they cover only a small proportion of the plant diversity of these forests. Nevertheless, this is the first report ever published on the mycorrhizal status of some of the species examined that belong to the Cyperaceae, Polygonaceae, Scrophulariaceae, and Juncaceae families.

Acknowledgements: This work was partially supported by funding from PROYUNGAS $(1999,2001)$ and C.I.C. (2005). A. Bercera is grateful to CONICET for the fellowship provided. M. Cabello is researcher from C.I.C.

\section{REFERENCES}

[1] Aceñolaza P.G., Estructura y dinámica de bosques de aliso (Alnus acuminata HBK subsp. acuminata) de la Provincia de Tucumán. Ph.D. thesis, National University of Tucumán, Argentina, 1995.

[2] Allsopp N., Stock W.D., Mycorrhizal status of plants growing in the Cape Floristic Region, South Africa, Bothalia 23 (1993) 91-104.

[3] Becerra A.G., Influencia de los Suelos Ustorthentes sobre las ectomicorrizas y endomicorrizas de Alnus acuminata H.B.K., Master thesis, UBA, Argentina, 2002.

[4] Becerra A., Daniele G., Domínguez L., Nouhra E., Horton T., Ectomycorrhizae between Alnus acuminata H.B.K. and Naucoria escharoides (Fr.:Fr.) Kummer from Argentina, Mycorrhiza 12 (2002) 61-66.

[5] Becerra A., Nouhra E., Daniele G., Domínguez L., McKay D., Ectomycorrhizas of Cortinarius helodes and Gyrodon monticola with Alnus acuminata from Argentina, Mycorrhiza 15 (2005) 7-15.

[6] Becerra A., Zak M.R., Horton T., Micolini J., Ectomycorrhizal and arbuscular mycorrhizal colonization of Alnus acuminata from Calilegua National Park (Argentina), Mycorrhiza 15 (2005) 525531.

[7] Becerra, A., Pritsch K., Arrigo N., Palma M., Bartoloni N., Ectomycorrhizal colonization of Alnus acuminata Kunth in northwestern Argentina in relation to season and soil parameters, Ann. For. Sci. 62 (2005) 325-332.

[8] Becerra, A., Cabello, M., Micorrizas arbusculares en plantines de Alnus acuminata (Betulaceae) inoculados con Glomus intraradices (Glomaceae), Bol. Soc. Arg. Bot. (2007) (in press).

[9] Bedini S., Maremmani A., Giovannetti M., Paris-type mycorrhizas in Smilax aspera L. growing in a Mediterranean scherophyllous wood, Mycorrhiza 10 (2000) 9-13.

[10] Bell D.A. Distribución del bosque de Aliso del Cerro, Alnus acuminata (Betulaceae) en la Provincia de Tucumán, Argentina, Bol. Soc. Arg. Bot. 27 (1991) 21-30.
[11] Béreau M., Garbaye J., First observation on the root morphology and symbioses of 21 major tree species in the primary tropical rain forest of French Guayana, Ann. Sci. For. 51 (1994) 407-416.

[12] Béreau M., Gazel M., Garbaye J., Mycorrhizal symbiosis in trees of tropical rainforest of French Guyana, Can. J. Bot. 75 (1997) 711716.

[13] Bever J.D., Schultz P.A., Pringle A., Morton J.B., Arbuscular mycorrhizal fungi: more diverse than meets the eye, and the ecological tale of why, BioSci. 51 (2001) 923-931.

[14] Braun-Blanquet J., Plant sociology: the study of plant communities. Transley review, in: Fuller G.D., Conard H.S. (Eds.), Hafner, London, 1965.

[15] Brown A., Placci G., Grau H.R., Ecología y biodiversidad de las Selvas Subtropicales de Argentina, in: Goñi F., Goin C. (Eds.), Principios de Política Ambiental, Cámara de Diputados de la Pcia. de Buenos Aires, Buenos Aires, 1993, pp. 215-222.

[16] Brundrett M., Mycorrhizas in natural ecosystems, Adv. Ecol. Res. 21 (1991) 171-262.

[17] Brundrett M., Kendrick B., The roots and mycorrhizas of herbaceous woodland plants. I. Quantitative aspects of morphology, New Phytol. 114 (1990) 457-468.

[18] Brundrett M., Abbott L., Jasper D., Malajczuk N., Bougher N., Brennan K., Ashwath N., Mycorrhizal associations in the Alligator Rivers Region. Part II. Results of experiments. Final report, Office of the Supervising Scientist, Jabiru NT, 1995.

[19] Brundrett M., Beegher N., Dell B., Groove T., Malajczuk N., Working with mycorrhizas in Forestry and Agriculture, ACIAR Monograph 32, 1996.

[20] Cabrera A.L., Fitogeografía de la República Argentina, Enciclopedia Argentina de Agronomía y Jardinería, Buenos Aires, 1976.

[21] Carrillo R., Godoy R., Peredo H., Simbiosis micorrícica en comunidades boscosas del Valle Central en el sur de Chile, Bosque 13 (1992) 57-67.

[22] Carú, M., Becerra, A., Sepúlveda, D., Cabello, A. Isolation of infective and effective Frankia strains from root nodules of Alnus acuminata (Betulaceae), World J. Microbiol. Biotech. 16 (2000) 647-651.

[23] Cavagnaro T.R., Gao L.-L., Smith F.A., Smith S.E., Morphology of arbuscular mycorrhizas is influenced by fungal identity, New Phytol. 151 (2001) 469-475.

[24] Cervantes, E., Rodriguez Barrueco, C., Relationships between the mycorrhizal and actinorhizal symbioses in non-legumes, in: Norris J.R., Read D.J., Varma A.K. (Eds.), Methods in Microbiology: Techniques for the study of mycorrhizal, Academic Press, London, 1992, pp 417-432.

[25] Dhillion S.S., Zak J.C., Microbial dynamics in arid ecosystems desertification and the potential role of mycorrhizas, Rev Chil. Hist. Nat. 66 (1993) 253-270.

[26] Dhillion S.S., Friese C.F., The occurrence of mycorrhizas in prairies: application to ecological restoration, Proceedings of the 13th North American Prairie Conference, University of Windsor Press, Windsor, Canada, 1994.

[27] Fontenla S., Godoy R., Rosso P., Havrylenko M., Root associations in Austrocedrus chilensis forests and seasonal dynamics of arbuscular mycorrhizas, Mycorrhiza 8 (1998) 29-33.

[28] Fontenla S., Punteri J., Ocampo J.A., Mycorrhizal associations in the Patagonian steppe, Argentina, Plant Soil 233 (2001) 13-29.

[29] Francis R., Read D.J., The contributions of mycorrhizal fungi to the determination of plant community structure, Plant Soil 159 (1994) $11-25$.

[30] Furlow J.J., The systematic of the American species of Alnus (Betulaceae), Rhodora 81 (1979) 1-241.

[31] Gallaud I., Études sur les mycorhizes endotrophes, Revue Générale Botanique 17 (1905) 5-48, 66-85, 123-136, 223-239, 313-325, 423-433, 479-500. 
[32] Gange A.C., Brown V.K., Sinclair G.S., Vesicular-arbuscular mycorrhizal fungi: a determinant of plant community structure in early succession, Funct. Ecol. 7 (1993) 616-622.

[33] Gerdemann J.W., Vesicular-arbuscular mycorrhizas formed on maize and tulip tree by Endogone fasciculate, Mycologia 57 (1965) $562-575$.

[34] Giovannetti M., Lioi L., The mycorrhizal status of Arbutus unedo in relation to compatible and incompatible fungi, Can. J. Bot. 68 (1990) 1239-1244.

[35] Giovannetti M., Sbrana C., Logi C., Early processes involved in host recognition by arbuscular mycorrhizal fungi, New Phytol. 127 (1994) 703-709.

[36] Giusti L., Slanis A., Aceñolaza P., Fitosociología de los bosques de aliso (Alnus acuminata H.B.K. ssp. acuminata) de Tucumán (Argentina), Lilloa 38 (1996) 93-120.

[37] Godoy R., Romero R., Carrillo R., Status micotrófico de la flora vascular en bosques de coníferas nativas del sur de Chile, Rev. Chil. Hist. Nat. 67 (1994) 209-220.

[38] Grau A., La expansión del aliso del cerro (Alnus acuminata H.B.K. subsp. acuminata) en el noroeste de Argentina, Lilloa 36 (1985) 237-247.

[39] Grime J.P., Mackey J.M., Miller S.H., Read D.J., Floristic diversity in a model system using experimental microcosm, Nature 328 (1987) 420-422.

[40] Harley J.L., Harley E.L., A check-list of mycorrhiza in the Bristh flora, New Phytol. 105 (1987) 1-102.

[41] Harley J.L., Harley E.L., A check-list of mycorrhiza in the Bristh flora-Addenda, errata and index, New Phytol. 107 (1987) 741-749.

[42] Harley J.L., Harley E.L., A check-list of mycorrhiza in the Bristh flora-second addenda and errata, New Phytol. 115 (1990) 699-711.

[43] Harley J.L., Smith S.E., Mycorrhizal symbiosis, Academic Press, London, 1983.

[44] Hartnett D.C., Wilson G.W.T., Mycorrhizae influence plant community structure and diversity in tallgrass prairie, Ecology 80 (1999) $1187-1195$

[45] Hartnett D.C., Wilson G.W.T., The role of mycorrhizas in plant community structure and dynamics: lessons from grasslands, Plant Soil 244 (2002) 319-331.

[46] Haselwandter K., Soil micro-organisms, mycorrhiza, and restoration ecology, in: Urbanska K.M., Webb N.R., Edwards P.J. (Eds.), Restoration ecology and sustainable development, Cambridge University Press, Cambridge, 1997, pp. 65-80.

[47] Heijden M.G.A. van der, Arbuscular mycorrhizal fungi as a determinant of plant diversity: in search of underlying mechanisms and general principles, in: van der Heijden M.G.A., Sanders I.R. (Eds.), Mycorrhizal ecology, Springer-Verlag, Berlin, 2002, pp. 243-265.

[48] Heijden M.G.A. van der, Boller T., Wiemken A., Sanders I.R., Different arbuscular mycorrhizal fungal species are potential determinants of plant community structure, Ecology 79 (1998) 20822091.

[49] Hueck K., Los bosques de Sudamérica, Soc. Alem. Coop. Tec., Eschborn, 1978.

[50] Janos D.P., Mycorrhizae influence tropical succession, Biotropica 12 (Suppl.) (1980) 56-64.

[51] Janos D.P., Vesicular-arbuscular mycorrhizae affect lowland tropical rain forest plant growth, Ecology 6 (1980) 151-162.

[52] Janos D.P., VA mycorrhizas in humid tropical ecosystems, in: Safir G.R. (Ed.), Ecophysiology of VA mycorrhizal plants, CRC Press, Boca Raton, FLA, 1987, pp. 107-134.

[53] Johnson D., Booth R.E., Whiteley A.S., Bailey M.J., Read D.J., Grime J.P., Plant community composition affects the biomass, activity and diversity of microorganisms in limestone grassland soil, Eur. J. Soil. Sci. 54 (2003) 671-677.
[54] Klironomos J.N., McCune J., Hart M., Neville J., The influence of arbuscular mycorrhizae on the relationship between plant diversity and productivity, Ecol. Lett. 3 (2000) 137-141.

[55] Lesueur D., Duponnois R., Relations between rhizobial nodulation and root colonization of Acacia crassicarpa provenances by an arbuscular mycorrhizal fungus, Glomus intraradices Schenk and Smith or an ectomycorrhizal fungus, Pisolithus tinctorius Coker \& Couch, Ann. For. Sci. 62 (2005) 467-474.

[56] Lovera M., Cuenca G., Arbuscular mycorrhizal infection in Cyperaceae and Gramineae from natural, disturbed and restored savannas in La Gran Sabana. Venezuela, Mycorrhiza 6 (1996) 111118 .

[57] Meney K.A., Dixon K.W., Scheltema M., Pate J.S., Occurrence of vesicular arbuscular mycorrhizal fungi in dryland species of Restionaceae and Cyperaceae from south-west Western Australia, Aust. J. Bot. 41 (1993) 733-737.

[58] Menoyo E., Becerra A., Renison D., Mycorrhizal associations in Polylepis woodlands of Central Argentina, Can. J. Bot. 85 (2007) 526-531.

[59] Miller R.M., Smith C.R., Jastrow J.D., Bever J.D., Mycorrhizal status of the genus Carex (Cyperaceae), Am. J. Bot. 86 (1999) 547553.

[60] Moyersoen B., Fitter A.H., Alexander I.J., Spatial distribution of ectomycorrhizas and arbuscular mycorrhizas in Korup National Park rain forest, Cameroon, in relation to edaphic parameters, New Phytol. 139 (1998) 311-320.

[61] Montenegro C., Strada M., Parmuchi G., Reserva de la Biósfera de las Yungas, Informe sobre la Desforestación, Secretaría de Ambiente y Desarrollo Sustentable, 2003, pp. 1-16.

[62] Mukerji K.G., Chamola B.P., Singh J., Mycorrhizal biology, Kluwer, New York, 2000.

[63] Newman E.I., Reddell P., The distribution of mycorrhizas among families of vascular plants, New Phytol. 106 (1987) 745-751.

[64] O'Connor P.J., Smith S.E., Smith F.A., Arbuscular mycorrhizas influence diversity and structure in a semi-arid plant community, in: Smith S.E. (Ed.), Diversity and Integration in Mycorrhizas, Proceeding 3rd International Conference on Mycorrhizas, Adelaide, South Australia, 2001.

[65] O'Connor P.J., Smith S.E., Smith F.A., Arbuscular mycorrhizas influence plant diversity and community structure in a semiarid herbland, New Phytol. 154 (2002) 209-218.

[66] Pate J.S., The mycorrhizal association: just one of many nutrient acquiring specializations in natural ecosystems, in: Robson A.D., Abbott L.K., Malajczuk N. (Eds.), Management of mycorrhizas in agriculture and forestry, Kluwer Academic Publishers, London, 1994, pp. 1-10.

[67] Phillips J.M., Hayman D.S., Improved procedures for clearing roots and staining parasitic and vesicular-arbuscular mycorrhizal fungi for rapid assessment of infection, Trans. Br. Mycol. Soc. 55 (1970) $158-161$

[68] Redhead J.F., Ectomycorrhizae in the tropics, in: Dommergues Y.R., Diem H.G. (Eds.), Mycrobiology of tropical soils and plant productivity, Nikhoff, Junk, The Hague, 1982, pp. 253-269.

[69] Rincón A., Parladé J., Pera J., Effects of ectomycorrhizal inoculation and the type of substrate on mycorrhization, growth and nutrition of containerised Pinus pinea $\mathrm{L}$. seedlings produced in a commercial nursery, Ann. For. Sci. 62 (2005) 1-6.

[70] Schenk N.C., Methods and principles of mycorrhizal research, The American Phytopathological Society, St. Paul, 1982.

[71] Sieverding E., Vesicular-arbuscular mycorrhizal management in tropical agrosystems, GTZ, Eschborn, Germany, 1991.

[72] Singer R., Araujo I.J.S., Litter descomposition and ectomycorrhiza in Amazonian forests. 1. A comparison of litter decomposing and ectomycorrhizal basidiomycetes in latosol-terra-firme rain forest and white podzol campinarana, Acta Amazonica 9 (1979) 25-41. 
[73] Siquiera J.O., Carneiro M.A.C., Curi N., Rosado S.C.S., Davide A.C., Mycorrhizal colonization and mycotrophic growth of native woody species as related to successional groups in southeastern Brazil, For. Ecol. Manage. 107 (1997) 241-252.

[74] Slanis A., La flora asociada al aliso del cerro (Alnus acuminata H.B.K. subsp. acuminata), Trabajo de Seminario, Biblioteca de la Fac. de Cs. Nat. e Instituto Miguel Lillo, National University of Tucumán, 1990.

[75] Smith S.E., Read D.J., Mycorrhizal Symbiosis, 2nd ed., Academic Press, London, 1997.

[76] Smith F.A., Smith S.E., Structural diversity in (vesicular)arbuscular mycorrhizal symbioses, Tansley Review $\mathrm{N}^{\circ} 96$, New Phytol. 137 (1997) 373-388.

[77] St John T.V., A survey of mycorrhizal infection in an Amazonian rain forest, Acta Amazonica 10 (1980) 527-533.

[78] Stampe D.E., Daehler C.C., Mycorrhizal species identity affects plant community structure and invasion: a microcosm study, Oikos 100 (2003) 362-372.

[79] Stenlund D.L., Charvat I.D., Vesicular arbuscular mycorrhizae in floating wetland mat communities dominated by Typha, Mycorrhiza 4 (1994) 131-137.
[80] Tester M., Smith S.E., Smith F.A., The phenomenon of nonmycorrhizal plants, Can. J. Bot. 65 (1987) 419-431.

[81] Trappe J.M., Phylogenetic and ecologic aspects of mycotrophy in the angiosperms from an evolutionary standpoint, in: Safir G.R. (Ed.), Ecophysiology of VA Mycorrhizal Plants, CRC Press, Boca Ratón, Florida, USA, 1987, pp. 5-25.

[82] Tsuyuzaki S., Hase A., Niinuma H., Distribution of different mycorrhizal classes on Mount Koma, northern Japan, Mycorrhiza 15 (2005) 93-100.

[83] Vargas Gil J.R., Bianchi A.R., Regiones Naturales del NOA. Memoria Anual de Información Técnica para productores, INTA, Salta, 1981.

[84] Yamato M., Morphological types of arbuscular mycorrhizal fungi in roots of weeds on vacant land, Mycorrhiza 14 (2004)127-131.

[85] Yamato M., Iwasaki M., Morphological types of arbuscular mycorrhizal fungi in roots of understory plants in Japanese deciduous broadleaved forests, Mycorrhiza 12 (2002) 291-296.

[86] Zhao Z.W., The arbuscular mycorrhizas of pteridophytes in Yunnan, southwest China: evolutionary interpretations, Mycorrhiza 10 (2000) 145-149. 